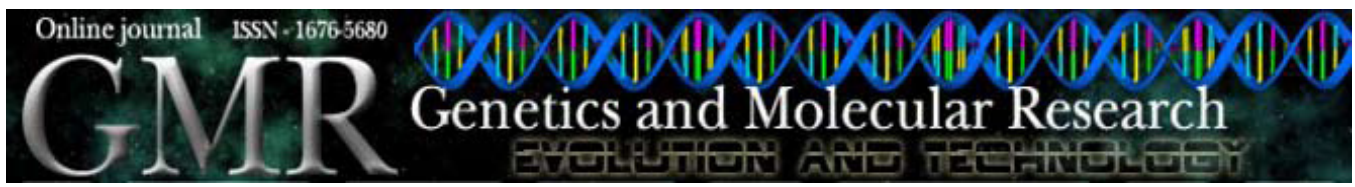

\title{
Karyotypic variability in Iheringichthys labrosus (Teleostei, Pimelodidae) from the Tibagi River basin (Paraná State, Brazil)
}

\author{
L.B. Ribeiro ${ }^{1}$, D.A. Matoso ${ }^{2}$, M.C. Almeida ${ }^{3}$, M.R. Vicari ${ }^{3}$, \\ A. Moraes-Neto ${ }^{3}$, M.C.C.M. Svidnicki ${ }^{3}$ and R.F. Artoni ${ }^{3}$ \\ ${ }^{1}$ Programa de Pós-Graduação em Genética, Conservação e Biologia Evolutiva, \\ Instituto Nacional de Pesquisas da Amazônia, Manaus, AM, Brasil \\ ${ }^{2}$ Programa de Pós-Graduação em Genética, Centro Politécnico, \\ Universidade Federal do Paraná, Curitiba, PR, Brasil \\ ${ }^{3}$ Departamento de Biologia Estrutural, Molecular e Genética, \\ Universidade Estadual de Ponta Grossa, Campus de Uvaranas, \\ Ponta Grossa, PR, Brasil \\ Corresponding author: R.F. Artoni \\ E-mail: rfartoni@pesquisador.cnpq.br
}

Genet. Mol. Res. 7 (3): 718-724 (2008)

Received May 2, 2008

Accepted July 2, 2008

Published August 14, 2008

\begin{abstract}
Cytogenetic analyses were carried out in a populational sample of Iheringichthys labrosus from the Guaraúna River (Upper Tibagi River; Paraná State, Brazil) in order to provide a karyotypic comparison with another previously studied population from the Lower Tibagi River, characterized by the presence of $32 \mathrm{~m}+8 \mathrm{sm}+6 \mathrm{st}+10 \mathrm{a}$ $(2 \mathrm{n}=56, \mathrm{FN}=102)$ and occurrence of supernumerary chromosomes ( $80 \%$ of individuals). The 17 specimens of I. labrosus (6 females, 10 males and 1 of unknown sex) from the Upper Tibagi River showed $2 \mathrm{n}=56$ chromosomes, a karyotype formula of $14 \mathrm{~m}+32 \mathrm{sm}+4 \mathrm{st}+$ $6 \mathrm{a}(\mathrm{FN}=106)$, without evidence of sex chromosome heteromorphism or supernumerary chromosomes. The heterochromatin was detected
\end{abstract}


at telomeric and centromeric positions in several chromosomal pairs. The Ag-nucleolar organizer regions were heteromorphic and located at terminal position on short arms of the 16th chromosomal pair, suggesting a positive association with heterochromatic regions. The inter-populational karyotypic differentiation reported indicates distinct evolutionary pathways within I. labrosus in the Tibagi River basin.

Key words: Karyotypic evolution; Cytotaxonomy; Heterochromatin; Ag-nucleolar organizer regions

\section{INTRODUCTION}

The Tibagi River basin comprises $550 \mathrm{~km}$ of the Tibagi River and 65 tributaries. Its ichthyofauna is composed of about 110 species, belonging predominantly to the orders Characiformes and Siluriformes (Shibatta et al., 2002). These species might present either a wide karyotypic variability in heterogeneous groups or a conserved karyotype structure (Artoni et al., 2000).

Amongst Siluriformes, the family Pimelodidae has been characterized by a constant diploid number $(2 \mathrm{n}=56)$ in most cytogenetically studied species (Dias and Foresti, 1993; Swarça et al., 2003). However, lower diploid numbers have been reported in some species, such as Pimelodella sp $(2 \mathrm{n}=46$ chromosomes), along with some cases of remarkable interindividual and inter-populational variability regarding $2 \mathrm{n}$ values and the presence of supernumerary chromosomes (Dias and Foresti, 1993).

The demersal catfish Iheringichthys labrosus, found in the Tibagi River and its major tributaries, ranges from small to medium sized individuals, with a grayish-silver coloration and small spots on the dorsal region (Shibatta et al., 2002). Previous studies have shown a diploid number of $2 \mathrm{n}=56$ chromosomes for this species, together with the presence of supernumerary chromosomes in $80 \%$ of individuals within the sampled population (Carvalho et al., 2004; Carvalho and Dias, 2005, 2007). In the present study, another I. labrosus population collected in the Upper Tibagi River basin was cytogenetically analyzed and compared, under a cytotaxonomic basis, with the available data of the population collected in the low portion of the Tibagi River.

\section{MATERIAL AND METHODS}

Seventeen specimens of I. labrosus (6 females, 10 males and 1 with unknown sex) were collected in the Guaraúna River, a left-margin tributary from the Upper Tibagi River basin (Ponta Grossa city, Paraná State, Brazil) (Figure 1).

The fish specimens were captured using traps and transported alive, under appropriate oxygen conditions, to the Laboratory of Fish Cytogenetics at Universidade Estadual de Ponta Grossa (PR), in order to obtain mitotic chromosomes. The chromosomal preparation followed the methodology described by Bertollo et al. (1978). Vouched specimens were identified by Dr. O.A. Shibatta and deposited in the Zoology Museum at Universidade Estadual de Londrina (Londrina, PR). Heterochromatin regions were detected according to Sumner (1972) and chromosomes were stained with propidium iodide. The nucleolar organizer regions (AgNORs) were analyzed after silver nitrate staining (Howell and Black, 1980). 
The karyotypes were organized into pairs in decreasing size order and chromosomes were classified as metacentric (m), submetacentric (sm), subtelocentric (st) and acrocentric (a), according to the arm ratio (Levan et al., 1964).

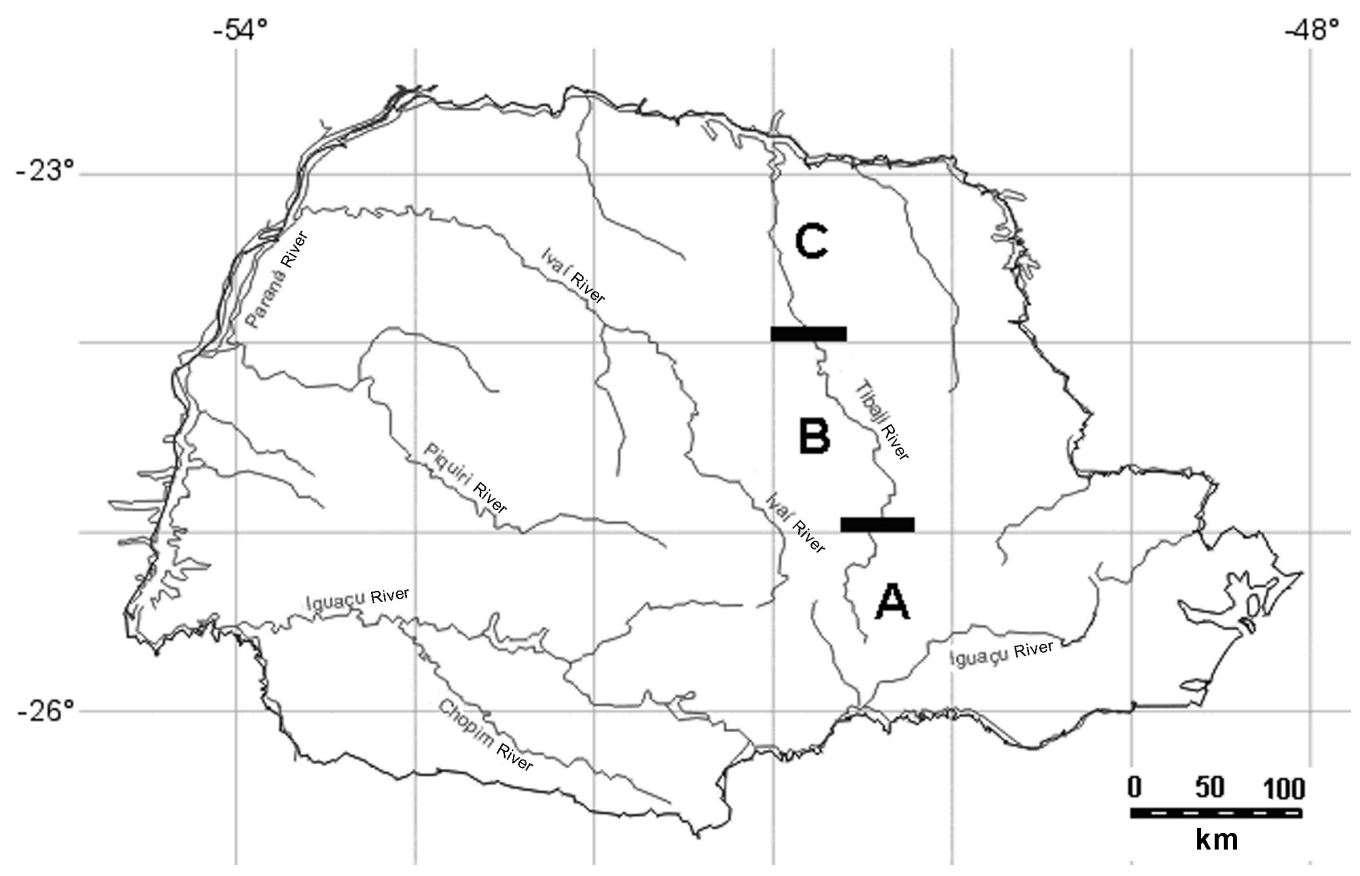

Figure 1. Map of Paraná State, Brazil, focusing on the Tibagi River basin. A. Upper Tibagi River. B. Middle Tibagi River. C. Lower Tibagi River.

\section{RESULTS}

The analysis of mitotic metaphases revealed the presence of $2 \mathrm{n}=56$ chromosomes in all studied specimens, without evidence of morphologically differentiated sex chromosome systems or supernumerary chromosomes. The karyotype is composed of 7 pairs of metacentric chromosomes, 16 pairs of submetacentric chromosomes, 2 pairs of subtelocentric chromosomes and 3 pairs of acrocentric chromosomes, with a fundamental number (FN) equal to 106 (Figure 2A).

The constitutive heterochromatin was faintly detected, in small amounts, over telomeric and centromeric segments of several chromosomes, especially located in the telomeric regions of the 2 nd chromosomic pair (Figure 2B). The NORs were heteromorphic and located at terminal position on short arms of the 16th submetacentric pair, associated with heterochromatic regions (Figure 2C). 

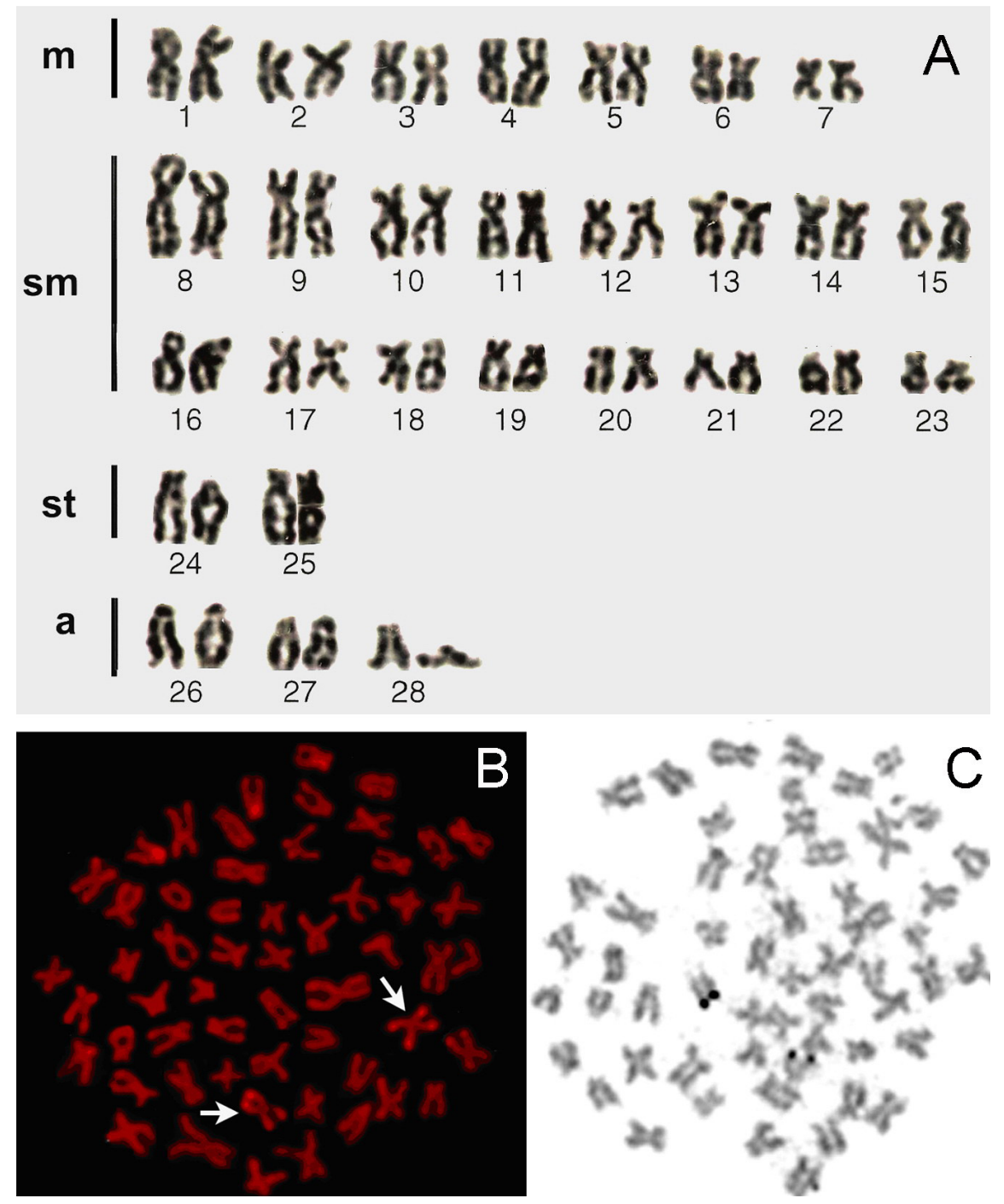

Figure 2. Karyotype and mitotic metaphase chromosomes of Iheringichthys labrosus from Upper Tibagi River after Giemsa staining (A), C-banding stain with propidium iodide (B) and impregnation with silver nitrate (C). The arrows indicate a metacentric chromosomal pair with bitelomeric heterochromatin segments in $\mathrm{B}$ and the chromosomes bearing Ag-NORs in $\mathrm{C} . \mathrm{m}=$ metacentric; $\mathrm{sm}=$ submetacentric; $\mathrm{st}=$ subtelocentric; $\mathrm{a}=$ acrocentric.

\section{DISCUSSION}

The diploid number of $2 \mathrm{n}=56$ chromosomes is the most frequent $2 \mathrm{n}$ value reported in the family Pimelodidae, including I. labrosus (Dias and Foresti, 1993; Vissoto et 
al., 1999; Carvalho et al., 2004). Nevertheless, the karyotype formula $(14 \mathrm{~m}+32 \mathrm{sm}+4 \mathrm{st}$ $+6 \mathrm{a}$ ) and an FN of 106, as observed in the present study, for the population of I. labrosus from the Upper Tibagi River, differs from that previously reported for another population of this species from the Lower Tibagi River. In the latter, a karyotype formula with $32 \mathrm{~m}+$ $8 \mathrm{sm}+6 \mathrm{st}+10 \mathrm{a}$ and an FN of 102 was detected (Carvalho et al., 2004; Table 1). The differentiation in the karyotype formula, showing either an increase or a decrease of chromosome arms without alterations in the diploid number (2n), suggests that non-Robertsonian chromosomal rearrangements have taken place, such as pericentric inversions, leading to the karyotypic variability observed in these populations. Although lower FN have been regarded as a basal condition for some Siluriforme families, such as Loricariidae (Artoni and Bertollo, 2001; Kavalco et al., 2005), ancestor features among distinct karyotypes can only be reliably defined by comparisons with outgroup comprising taxonomically related species, in order to polarize the transformation sequence in the FN. In this context, it is impossible to define, at the moment, which karyotypic formula of the I. labrosus is more conserved or derived.

Table 1. Frequency of B-chromosomes in somatic cells of Iheringichthys labrosus from the Tibagi River basin.

\begin{tabular}{|c|c|c|c|c|c|c|c|}
\hline \multirow[t]{2}{*}{ Individual number/sex } & \multirow[t]{2}{*}{ 2n/FN/karyotype } & \multicolumn{4}{|c|}{$\begin{array}{c}\text { Number of } \\
\text { B-chromosomes }\end{array}$} & \multirow[t]{2}{*}{ Total of cells } & \multirow[t]{2}{*}{ Ref. } \\
\hline & & 0 & 1 & 2 & 3 & & \\
\hline $1 \mathrm{~F}$ & $56 / 106 / 14 m+32 s m+4 s t+6 a$ & 11 & 0 & 0 & 0 & 11 & 1 \\
\hline $2 \mathrm{M}$ & $56 / 106 / 14 m+32 s m+4 s t+6 a$ & 32 & 0 & 0 & 0 & 32 & 1 \\
\hline $3 \mathrm{M}$ & $56 / 106 / 14 m+32 s m+4 s t+6 a$ & 14 & 0 & 0 & 0 & 14 & 1 \\
\hline $4 \mathrm{~F}$ & $56 / 106 / 14 m+32 s m+4 s t+6 a$ & 37 & 0 & 0 & 0 & 37 & 1 \\
\hline $5 \mathrm{I}$ & $56 / 106 / 14 m+32 s m+4 s t+6 a$ & 3 & 0 & 0 & 0 & 3 & 1 \\
\hline $6 \mathrm{~F}$ & $56 / 106 / 14 m+32 s m+4 s t+6 a$ & 12 & 0 & 0 & 0 & 12 & 1 \\
\hline $7 \mathrm{M}$ & $56 / 106 / 14 m+32 s m+4 s t+6 a$ & 8 & 0 & 0 & 0 & 8 & 1 \\
\hline $8 \mathrm{M}$ & $56 / 106 / 14 m+32 s m+4 s t+6 a$ & 5 & 0 & 0 & 0 & 5 & 1 \\
\hline $9 \mathrm{~F}$ & $56 / 106 / 14 m+32 s m+4 s t+6 a$ & 4 & 0 & 0 & 0 & 4 & 1 \\
\hline $10 \mathrm{M}$ & $56 / 106 / 14 m+32 s m+4 s t+6 a$ & 17 & 0 & 0 & 0 & 17 & 1 \\
\hline $11 \mathrm{M}$ & $56 / 106 / 14 m+32 s m+4 s t+6 a$ & 15 & 0 & 0 & 0 & 15 & 1 \\
\hline $12 \mathrm{M}$ & $56 / 106 / 14 m+32 s m+4 s t+6 a$ & 11 & 0 & 0 & 0 & 11 & 1 \\
\hline $13 \mathrm{M}$ & $56 / 106 / 14 m+32 s m+4 s t+6 a$ & 5 & 0 & 0 & 0 & 5 & 1 \\
\hline $14 \mathrm{M}$ & $56 / 106 / 14 m+32 s m+4 s t+6 a$ & 9 & 0 & 0 & 0 & 9 & 1 \\
\hline $15 \mathrm{M}$ & $56 / 106 / 14 m+32 s m+4 s t+6 a$ & 6 & 0 & 0 & 0 & 6 & 1 \\
\hline $16 \mathrm{~F}$ & $56 / 106 / 14 m+32 s m+4 s t+6 a$ & 21 & 0 & 0 & 0 & 21 & 1 \\
\hline $17 \mathrm{~F}$ & $56 / 106 / 14 m+32 s m+4 s t+6 a$ & 4 & 0 & 0 & 0 & 4 & 1 \\
\hline $18 \mathrm{~F}$ & $56 / 102 / 32 \mathrm{~m}+8 \mathrm{sm}+6 \mathrm{st}+10 \mathrm{a}$ & 23 & 7 & 0 & 0 & 30 & 2 \\
\hline $19 \mathrm{M}$ & $56 / 102 / 32 m+8 s m+6 s t+10 a$ & 28 & 1 & 0 & 0 & 29 & 2 \\
\hline $20 \mathrm{~F}$ & $56 / 102 / 32 \mathrm{~m}+8 \mathrm{sm}+6 \mathrm{st}+10 \mathrm{a}$ & 31 & 4 & 0 & 0 & 35 & 2 \\
\hline $21 \mathrm{M}$ & $56 / 102 / 32 \mathrm{~m}+8 \mathrm{sm}+6 \mathrm{st}+10 \mathrm{a}$ & 34 & 0 & 0 & 0 & 34 & 2 \\
\hline $22 \mathrm{~F}$ & $56 / 102 / 32 m+8 s m+6 s t+10 a$ & 37 & 0 & 0 & 0 & 37 & 2 \\
\hline $23 \mathrm{M}$ & $56 / 102 / 32 \mathrm{~m}+8 \mathrm{sm}+6 \mathrm{st}+10 \mathrm{a}$ & 22 & 10 & 7 & 8 & 47 & 2 \\
\hline $24 \mathrm{~F}$ & $56 / 102 / 32 m+8 s m+6 s t+10 a$ & 13 & 27 & 4 & 4 & 48 & 2 \\
\hline $25 \mathrm{~F}$ & $56 / 102 / 32 \mathrm{~m}+8 \mathrm{sm}+6 \mathrm{st}+10 \mathrm{a}$ & 9 & 11 & 8 & 4 & 32 & 2 \\
\hline $26 \mathrm{~F}$ & $56 / 102 / 32 \mathrm{~m}+8 \mathrm{sm}+6 \mathrm{st}+10 \mathrm{a}$ & 48 & 4 & 0 & 0 & 52 & 2 \\
\hline $27 \mathrm{M}$ & $56 / 102 / 32 m+8 s m+6 s t+10 a$ & 52 & 2 & 0 & 0 & 54 & 2 \\
\hline $28 \mathrm{I}$ & $56 / 102 / 32 m+8 s m+6 s t+10 a$ & 22 & 6 & 4 & 2 & 54 & 2 \\
\hline
\end{tabular}

$\mathrm{M}=$ male; $\mathrm{F}=$ female; $\mathrm{I}=$ unknown sex; $2 \mathrm{n}=$ diploid number; $\mathrm{FN}=$ fundamental number; 1 = present study; $2=$ Carvalho et al. (2004). 
Another remarkable karyotypic differentiation between the two studied populations of I. labrosus can also be pointed out. The Lower Tibagi River population, studied by Carvalho et al. (2004), showed supernumerary chromosomes in 9 of 11 specimens (frequency $=80 \%$ ). Inversely, in our study comprising 17 specimens from the Upper Tibagi River, no evidence of supernumerary chromosomes was found. The presence of supernumerary chromosomes has been frequently reported in several Neotropical fish groups, reflecting a putative condition of both random and parasitic meiotic segregation in relation to the standard complement (Camacho et al., 2000). These extra-chromosomes have been considered to be important indicators of populational differences. For instance, Artoni et al. (2006), analyzing a migratory Neotropical fish species (Prochilodus lineatus), detected differences in the number and morphology of supernumerary chromosomes between two populations from the Upper Paraná River basin. Although these chromosomes share a common origin, related to the formation of isochromosomes, the selective pressure on distinct populations has, supposedly, led to the outcome of both different types and frequencies of supernumerary chromosomes in each population of Prochilodus lineatus. A similar scenario might be hypothesized for the two populations of I. labrosus, or the presence of these distinguishable chromosomes could represent a single and apomorphic feature for $I$. labrosus from the Lower Tibagi River.

The centromeric and telomeric poorly marked heterochromatin has been commonly observed on chromosomes of members of the family Pimelodidae (Fenocchio and Bertollo, 1992; Swarça et al., 2003). Nonetheless, I. labrosus from the Upper Tibagi River reveals the presence of conspicuous heterochromatic bands on both short and long arms of the 2nd metacentric pair, which might represent a cytogenetic marker for the population herein analyzed. Such a situation has been frequently reported in some species of pimelodids and heptapterids, suggesting that this chromosome could constitute a shared feature and a marker trait for both families (Garcia and Moreira-Filho, 2005).

Heteromorphisms of NORs are very common in fish and they are likely determined by unequal cross-over, gene duplication, transposition, or other rearrangements involving homologous chromosomal segments (Borin and Martins-Santos, 1999; Vicari et al., 2003, 2006). Such NOR heteromorphic condition has already been formerly reported in a population of $I$. labrosus from the Capivara reservoir, Paraná, Brazil (Carvalho and Dias, 2007). Thus, this polymorphic variability involving activity of ribosomal cistrons is also present in I. labrosus from the Upper Tibagi River, although the presence of a single-nucleolar organizing chromosomic pair seems to be common and ancestral among the pimelodids.

In conclusion, the karyotypic differentiation found among the populations of $I$. labrosus indicates that these groups could be restricted in their environmental range related to distinct evolutionary pathways for each population. The behavior of the studied species, a non-migratory demersal fish, would favor the degree of karyotypic differentiation found, reinforcing the possible occurrence of reproductively isolated populations within the same hydrographic basin.

\section{ACKNOWLEDGMENTS}

We thank Dr. O.A. Shibatta for identifying the specimens and to Miguel A. Carvalho for the technical support. Research supported by CNPq and Fundação Araucária. 


\section{REFERENCES}

Artoni RF and Bertollo LA (2001). Trends in the karyotype evolution of Loricariidae fish (Siluriformes). Hereditas 134: 201-210.

Artoni RF, Vicari MR and Bertollo LAC (2000). Neotropical fish cytogenetics. Methods, results and perspectives. Publ. $U E P G$ 4: 43-60.

Artoni RF, Vicari MR, Endler AL, Cavallaro ZI, et al. (2006). Banding pattern of A and B chromosomes of Prochilodus lineatus (Characiformes, Prochilodontidae), with comments on B chromosomes evolution. Genetica 127: 277-284.

Bertollo LAC, Takahashi CS and Moreira-Filho O (1978). Cytotaxonomic considerations of Hoplias Lacerdae (Pisces, Erythrinidae). Braz. J. Genet. 1: 103-120.

Borin LA and Martins-Santos IC (1999). Karyotype characterization of three species of the genus Trichomycterus (Teleostei, Siluriformes) from the Iguaçu River basin. Genetica 106: 215-221.

Camacho JPM, Sharbel TF and Beukeboom LW (2000). B chromosome evolution. Phil. Trans. R. Soc. Lond. B 355: 163-178.

Carvalho RA and Dias AL (2005). Karyotypic characterization of Iheringichthys labrosus (Pisces, Pimelodidae): C-, Gand restriction endonuclease banding. Genet. Mol. Res. 4: 663-667.

Carvalho RA and Dias AA (2007). Individual size heteromorphism of NOR and chromosomal location of 5S rRNA genes in Iheringichthys labrosus. Braz. Arch. Biol. Technol. 50: 141-146.

Carvalho RA, Giuliano-Caetano L and Dias AL (2004). Cytogenetic analysis of A- and B-chromosomes of Iheringichthys labrosus (Pisces, Pimelodidae) from the Tibagi River, Paraná, Brazil. Cytologia 69: 381-385.

Dias AL and Foresti F (1993). Cytogenetic studies on fishes of the family Pimelodidae (Siluroidei). Rev. Bras. Genet. 16: 585-600.

Fenocchio AS and Bertollo LA (1992). Karyotype similarities among Pimelodidae (Pisces, Siluriformes) from the Brazilian Amazon region. Cytobios 69: 41-46.

Garcia C and Moreira-Filho O (2005). Cytogenetical analyses in three fish species of the genus Pimelodus (Siluriformes: Pimelodidae) from rio São Francisco: considerations about the karyotypical evolution in the genus. Neotrop. Ichthyol. 3: $285-290$.

Howell WM and Black DA (1980). Controlled silver-staining of nucleolus organizer regions with a protective colloidal developer: a 1-step method. Experientia 36: 1014-1015.

Kavalco KF, Pazza R, Bertollo LA and Moreira-Filho O (2005). Karyotypic diversity and evolution of Loricariidae (Pisces, Siluriformes). Heredity 94: 180-186.

Levan A, Fredga K and Sandberg AA (1964). Nomenclature for centromeric position on chromosomes. Hereditas 52: 201-220.

Shibatta OA, Orsi ML, Benemann ST and Silva-Souza A (2002). Diversidade e Distribuição de Peixes na Bacia do Rio Tibagi. In: A Bacia do Rio Tibagi (Medry M, Bianchini E, Shibatta OA and Pimenta JA, eds.). Ed. Univ. Estadual de Londrina, Londrina, 403-423.

Sumner AT (1972). A simple technique for demonstrating centromeric heterochromatin. Exp. Cell Res. 75: 304-306.

Swarça AC, Fenocchio AS, Cestari MM and Dias AL (2003). Analysis of heterochromatin by combination of C-banding and $\mathrm{CMA}_{3}$ and DAPI staining in two fish species (Pimelodidae, Siluriformes). Genetica 119: 87-92.

Vicari MR, Artoni RF and Bertollo LA (2003). Heterochromatin polymorphism associated with 18S rDNA: a differential pathway among Hoplias malabaricus fish populations. Cytogenet. Genome Res. 101: 24-28.

Vicari MR, Almeida MC, Bertollo LAC, Moreira-Filho O, et al. (2006). Cytogenetic analysis and chromosomal characteristics of the polymorphic $18 \mathrm{~S}$ rDNA in the fish Prochilodus lineatus (Characiformes, Prochilodontidae). Genet. Mol. Biol. 29: 621-625.

Vissoto PC, Foresti F and Oliveira C (1999). Karyotype description of five species of Pimelodidae (Teleostei, Siluriformes). Chromosome Sci. 3: 1-7. 